\title{
State and trends of depreciation strategy of rocket and space industry enterprises formation
}

\author{
Boyko Andrei Anatolievich \\ (a) Dept. of Management \\ Siberian Federal University, \\ (b) Dept. of Management \\ Reshetnev Siberian State University of Science and \\ Technology \\ Krasnoyarsk, Russia
}

Tynchenko Vadim Sergeevich

(a) Dept. of Production Machinery and Equipment for Petroleum and Natural Gas Engineering

Siberian Federal University,

(b) Dept. of Information Control Systems

Reshetnev Siberian State University of Science and

Technology

Krasnoyarsk, Russia

\author{
Kukartsev Vladislav Viktorovich \\ (a) Dept. of Informatics \\ Siberian Federal University, \\ (b) Dept. of Information Economic Systems \\ Reshetnev Siberian State University of Science and \\ Technology \\ Krasnoyarsk, Russia
}

\author{
Nasyrov Ilnar Rafinatovich \\ Military Training Center \\ Reshetnev Siberian State University of Science and \\ Technology \\ Krasnoyarsk, Russia
}

\author{
Kukartsev Viktor Alekseevich \\ Dept. of Material Science and Technology of Metal Processing \\ Siberian Federal University \\ Krasnoyarsk, Russia
}

\begin{abstract}
Russia's rocket and space industry should become an economically sustainable, developing along an innovative path, competitive, diversified industry capable of solving strategic tasks of improving and developing rocket and space assets. That should be done in the interests of national security, socio-economic sphere, science and international cooperation, ensuring guaranteed access and the necessary presence of Russia in outer space, the preservation and strengthening of its positions on the world space market. To this end, it is envisaged to bring the industry in line with modern requirements through technical re-equipment and creation of conditions for the introduction of modern technologies; optimization of the composition of production capacities followed by the sale of surplus assets. That also includes development of related industries; ensuring the concentration of available material, technical, financial and intellectual resources in sectors that have remained competitive in the global space market; transition to competition in other market segments. Depreciation charges are a primary source of renewal of fixed assets in the rocket and space industry. But at the present time this source of investment resources has lost its reproductive function. To solve this problem, it is necessary to develop a clear and adequate amortization strategy for the enterprises of the rocket and space industry that corresponds to the current reproductive situation. And for this, it is necessary to
\end{abstract}

improve the methods and tools for developing the amortization strategy of enterprises in the rocket and space industry.

Keywords - reproduction of fixed assets, depreciation, source of investment financing, depreciation strategy.

\section{INTRODUCTION}

The rocket and space industry (RSI) of Russia is the most knowledge-intensive and highly technological branch, which is the essential element of the Russian Federation's space potential.

The domestic rocket and space industry, unlike the analogous industries of the leading rocket and space powers of the world, was created in a highly-centralized economy, which allowed it to accumulate scientific, production, and technological potential, but didn't create a mechanism for the functioning of the RSI in a market economy.

In the 1990s, there was a quality in the nature of the reproduction of fixed assets (FAS). The aging process of fixed assets (especially the active part) has become determined by the unacceptably low rate of disposal of obsolete equipment 
for the modern economy and by the same low rates of introduction of new capital.

\section{STUDY OF ROCKET AND SPACE INDUSTRY}

Depreciation of fixed assets of enterprises of the defense complex is $60-65 \%$, and the coefficient of their renewal is 3$5 \%$. The assessment "critical" is quite suitable for the state of the industrial equipment since more than half of the main equipment is worn out and works conditionally only. It will take at least 10 years to replace it at the specified rates.

Another feature of the state FAS RSI, that turns it as a serious obstacle to the normal operation of defense enterprises, is the presence of excess production capacity.

The combination of these two problems creates a vicious cycle. Low volumes of orders lead to underutilization of capacities, decrease of profitability and failures in the technological chain, as the vast majority of enterprises of the military-industrial complex are designed for large-scale production. However, if the volume of orders is increased to the medium series, they are not able to meet it on time at the proper level of quality due to the lack of necessary equipment. Consequently, there is uncertainty and the resulting risks.

As a result of the rapid deceleration in the rate of reproduction of fixed assets, the age parameters of the used production equipment have been deteriorated (table 1). The rocket and space industry has the most unsatisfactory age structure of machinery and equipment among all branches of the military and industrial complex (MIC). The average age of machines and equipment in the RSI is 22 years. The share of new equipment up to 10 years is minimal 2,2\% (1991 about $50 \%$ ) and vice versa, the share of equipment beyond the normative useful lifetime (20 years) is maximal $70 \%$.

TABLE I. AGE STRUCTURE OF MACHINERY AND EQUIPMENT BY BRANCHES OF MILITARY-INDUSTRIAL COMPLEX, $(\%)$

\begin{tabular}{|c|c|c|c|c|c|c|c|}
\hline Age structure & MIC & AI & RSI & ICA & ASCI & SI & REC \\
\hline $\begin{array}{c}\text { All equipment } \\
\text { (at the end of the } \\
\text { year) }\end{array}$ & 100 & 100 & 100 & 100 & 100 & 100 & 100 \\
\hline \multicolumn{7}{|c|}{ where at the ages (year): } \\
\hline up to 5 & 9,2 & 18 & 0,5 & 3,8 & 7 & 1,8 & 11 \\
\hline from 5 to 10 & 9,3 & 9,2 & 1,7 & 9 & 14 & 4,2 & 15 \\
\hline from 10 to 20 & 36,3 & 38,1 & 27,8 & 31,8 & 40 & 37 & 44 \\
\hline more than 20 & 45,2 & 34,7 & 70 & 55,4 & 39 & 57 & 30 \\
\hline $\begin{array}{c}\text { Average age of } \\
\text { equipment, years }\end{array}$ & 17 & 15,5 & 22 & 19 & 17 & 20 & 15,5 \\
\hline
\end{tabular}

Table designations: MIC - military and industrial complex, AI - aircraft industry, RSI - rocket and space industry, ICA conventional arms industry, ASCI - industry of ammunition and special chemistry, SI - shipbuilding industry, REC radio-electronic complex.

The increase of the average age of the equipment leads to an increase of the share of machines for which depreciation is not accrued. In 2008, the cost of fully worn-out FAS as a whole for the RSI was $19.1 \%$, including for industrial enterprises was $21.7 \%$, in scientific organizations was $18.3 \%$ of the value of fixed assets. Fixed assets in the structure of RSI noncurrent assets tend to decrease from $67 \%$ in 2007 to $45 \%$ in 2010. The share of depreciation in expenses of the RSI remains almost unchanged at 1.4 percent in 2007 and 1.8 percent in 2010. As a result, the company's own investment resources of reproduction of FAS enterprises, such as depreciation Fund, are reduced.

\section{MAIN PROBLEMS INVESTIGATION}

Thus, the main problems of RSI enterprises reproduction are low rates of FAS reproduction, excess production capacity, high physical and moral depreciation of equipment, which reached a critical level and as a consequence the low level of capacity utilization.

The reasons for these problems are the outdated structure of production; methods of organization and production management; lack of investment resources of FAS reproduction; mismatch of the equipment, produced by domestic enterprises in the construction industry in its structure; quality and scope of needs of RSI enterprises.

According to the majority of experts, the lack of investment resources is one of the main reasons inhibiting the growth of the efficiency of FAS reproduction.

With the development of market relations and the corporatization of enterprises, array of new investment sources in fixed assets (for example, the issue of shares, accelerated depreciation, leasing, etc.) appeared and theoretically expanded the opportunities for the formation of investment resources for the reproduction of FAS. However, many sources that widely used by companies in developed market economies continue to be inaccessible to our enterprises due to the high cost of attracting these sources or the availability of investment restrictions.

In practice, most of the Russian enterprises in the RCP experience a chronic shortage of resources to defrayal their investment costs. Post-tax profits are often distributed in favor of "consumption" and to the detriment of savings; long-term Bank loans and leases are not available to all businesses. This is not just about their creditworthiness. Many Russian banks simply don't have their own capital, which is sufficient for long-term lending, and the funds raised (mostly for less than one year) cannot be used as a source for issuing long-term loans.

According to the majority of experts, one of the main reasons restraining the growth of reproduction efficiency of FAS is the lack of investment resources both in the MIC in general and in the RSI.

The structure of investment in the military-industrial complex by industries used for the reproduction of fixed productive assets is shown in Figure 1.

In the end, the investment structure used for reproduction of the RSI basic production assets are as follows: own funds and $91.7 \%$, raised to $8.3 \%$.

The structure of MIC investments by sectors at the expense of own funds used for the reproduction of fixed productive assets is shown in Figure 2. 


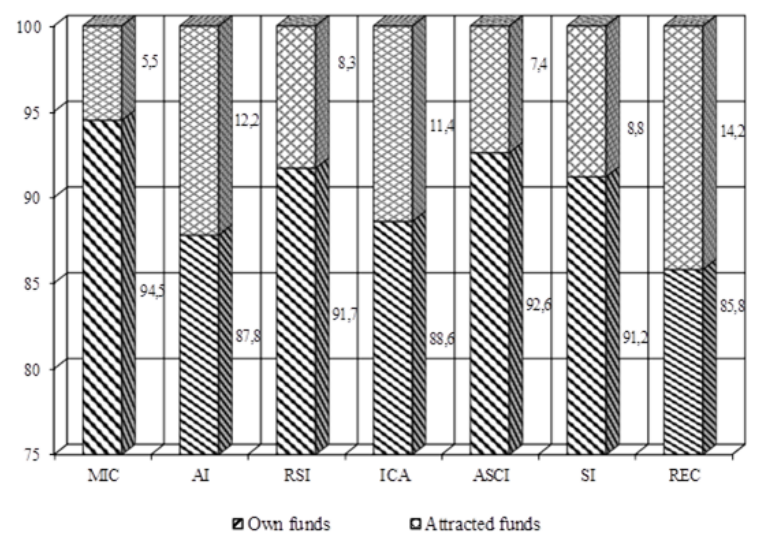

Fig. 1. Structure of investment in the military-industrial complex (\%).

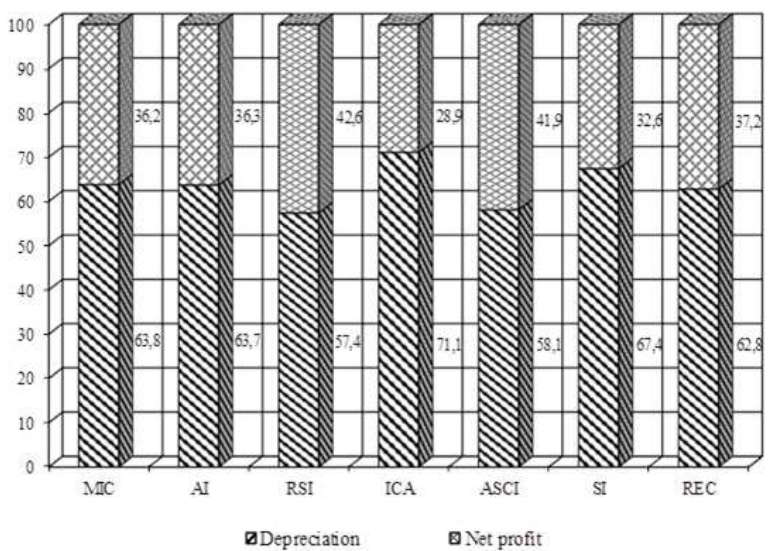

Fig. 2. Structure of investment in the military-industrial complex at the expense of own funds $(\%)$.

The main sources of financing investment in fixed assets for the vast majority of branches of the military-industrial complex are depreciation, their share is from $57.4 \%$ - the RSI to $71.1 \%$ - ICA, the share of net profit from $28.9 \%$ - ICA to $42.6 \%$ - RSI.

The main own source of financing investments in fixed assets for the RSI is depreciation charges, its share is $57.4 \%$ (42.6\% is net profit). In 2010 investments in MIC due to depreciation increased to $63.8 \%$. A similar situation is observed in all sectors.

Nowadays enterprises are constantly emerging significant deviation from the implementation of the depreciation reproductive function. For example, at the production stage, not all organizations create a depreciation Fund to accumulate funds to Finance the replacement of disposal facilities. But even if it is created under conditions when Bank interest on deposits is lower than the inflation rate, accumulated funds in the depreciation Fund will not be sufficient to ensure simple reproduction of fixed assets.

In modern conditions of market economy, the amount of accumulated depreciation has become some kind of consumption, regulating the level of the tax burden depending on the industries where the organization-taxpayer, which owns a certain list of depreciable facilities like property, plant, and equipment, operates.

Expenses are recognized as reasonable and documented costs incurred by the taxpayer. Justified expenses mean economically justified costs, assessing in monetary form (Art. 252 of the Tax Code of the Russian Federation (tax code)). Such expense as the amounts of the added depreciation (depreciation charges), in the conditions of the market relations, is not economically justified because it doesn't carry out the main function - reproduction.

Depreciation amounts can be accrued even in the absence of income, creating a loss. It can be recognized as an expense that will reduce income tax later (Art. 283 of the tax code).

The current legislation doesn't provide actual transferring of the depreciation amount to anyone.

No one of these characteristics is not peculiar to any of the expenses that are a part of the market price and they are involved in the formation of profit (loss).

These exceptional features, peculiar only to depreciation, confirm that depreciation artificially inflates both costs and revenues. With the reduction of the useful life of fixed assets, artificial overstatement of expenses, withdrawal from the population through the price factor of money and income increases only, resulting in the suppression of reproduction processes in the natural environment.

It's possible to allocate the following reasons of depreciation reproduction function loss: inappropriate using of depreciation charges, because of lack of control from the state behind formation and use of depreciation funds of the enterprises; imperfection of the legislation; inflation; lack of accurately formulated depreciation strategy of the enterprise.

So, the amount of the added depreciation on depreciation of fixed assets in commercial organizations only, excluding subjects of small business in billion rubles: 2007 - 1542, 2008 - 1907, 2009 - 2348, 2010 - 2669, 2011 - 3148. And invested depreciation in fixed assets of enterprises and organizations in general on the national economy in billion rubles: $2007-920$ (59.66\%), 2008 - 1161 (60.88\%), 2009-1101 (46.89\%), 2010 $-1359(50.92 \%), 2011-1663(52.83 \%)$. In the period under review, a little more than half of the money resources are aimed at updating OPF.

Obviously, not all depreciation charges were used for the intended purpose. Thus, Mikhail Sokolov, an expert of the Institute of Economics of the Russian Academy of Sciences, notes that in pre-crisis 2008, RUB 748.3 billion (39.2\%) was spent from the total accrued depreciation of RUB 1907.6 billion for purposes not related to investments in fixed assets, including the purchase of shares and other securities - RUB 580 billion $(30.4 \%)$.

Why is it possible to use this source of financing capital investments for other purposes, if it has no other purpose by its economic nature? The reason for this is that in modern Russian practice there is no control on the part of the state for the formation and use of depreciation funds of enterprises.

Currently, there is no specialized competent authority that develops depreciation policy, which controls its 
implementation in the Russian Federation. There is no analog of the US internal revenue service (Internal Revenue Service), that can not only collect taxes but also engaged in the practical implementation of the depreciation policy of the Federal Government.

The fact of carrying out the state depreciation policy in the Russian Federation is confirmed now by existence only two documents (the Tax code of the Russian Federation and the order of the Government of the Russian Federation of 01.01.2002 N 1 "about Classification of the fixed assets included in depreciation groups") defining the size of the added depreciation which control of target use is not included in anybody's competence.

Modern Russian policy in the field of depreciation of fixed assets is determined by the fiscal interests of the state and isn't focused on the modernization of the domestic enterprise's production base.

At the same time, in the United States, for instance, the Federal Government is pursuing an active depreciation policy focused on the intensive introduction of advanced technologies and the immediate replacement of obsolete fixed assets.

The materialized result of the difference between the Russian and American models of depreciation policy is as follows: in total investments in fixed assets of the Russian Federation enterprises, depreciation accounts are $17.3 \%$ only. For example, in the United States, this value is $74.2 \%$, which is 4.3 times more.

As for the tax legislation of the Russian Federation, it has been actively reformed in recent years. Along with it, the depreciation policy in Russia is being improved too. However, there are certain problems.

All measures aimed at the implementation of accelerated depreciation have not led to significant improvements in solving the problem of the renovation of fixed assets. When the retirement rate equal to $0.8 \%$, the cycle of updating the fixed assets will be 125 years. Thus, the increase in depreciation rates in the legislative and regulatory documents doesn't automatically reduce the service life of facilities and their accelerated replacement with more productive and efficient analogs.

In the run-up to 2009 , the approach to depreciation calculation for the purpose of the organizations' profit taxation was conceptually revised. The procedure of depreciation calculation using the linear method in the tax code was fundamentally changed.

The tax code currently stipulates that the choice of depreciation method of linear depreciation is charged in respect of separate objects of the fixed asset or intangible asset, but in the whole depreciation group (point 2 of article 259.2 of the RF tax code).

So, at the legislative level, it was determined the possibility of abandoning the object of depreciation and provided for the possibility of depreciation by the method of decreasing the balance on the enlarged depreciation groups (pools).
The accounting of the enlarged object, which doesn't reveal the cost and service life of its components, doesn't allow to estimate adequately the possible terms of replacement of components and the cost of their renewal on the basis of accounting data.

Also in accounting application of terms of useful use of fixed assets according to the all-Russian qualifier of fixed assets (it is approved by the resolution of Gosstandart of Russia of December 26, 1994 N 359) leads to overestimation of degree of depreciation of fixed assets, and to the fact that this indicator is actually not taken into account when planning replacement of technological objects.

\section{RESULTS OF STUDY}

So, the results of improving the depreciation policy are two types of innovations. Some innovations find practical application in modern market conditions of financial and economic activity of the organizations mainly because the new provisions of the tax legislation don't give alternative options of a choice: to apply them or not to apply. Other innovations don't find practical application and remain within the framework of legislative acts only.

Such theoretical innovations, in particular, include not only a non-linear method of depreciation calculation but also the right granted by the legislator to include the expenses of the reporting (tax) period capital expenditure.

As the practice of tax accounting of fixed assets shows the cases of the taxpayers' right application to include in the expenses of the reporting ( $\operatorname{tax})$ period, capital expenditure is extremely rare.

Calculations explain this fact. It shows that even taking into account additional to depreciation amounts of expenses on capital investments in the form of "the depreciation bonus" can't get over the inflation barrier that, in turn, leads to the impossibility of use of depreciation on its direct purpose is not overcome.

High inflation also leads to an unjustified increase in the company's need for working capital, because the company's costs for raw materials, wages, depreciation and other elements accounted for in the cost of production at the prices of the previous period, don't reimburse the number of real costs of the enterprise in the current period.

Frequently, net profit is not enough even to replenish working capital (the ratio of its own working capital of enterprises producing machinery and equipment lowered on $4 \%$ in 2010, and on $7.5 \%$ in 2011), not to mention its participation in a simple and even more extended reproduction of the FAS.

To reduce the negative impact of inflation and to solve the problem of accumulation of accrued depreciation is possible by introducing mandatory transfer of depreciation on special Deposit Bank accounts without the right to withdraw these funds by the owners before the expiration of the depreciation period of fixed assets. Moreover, it is extremely necessary for the state to ensure real profitability of these accounts, so that the storage of money for a long period of time is economically forest-like. 
It should be noted that at the moment the enterprises don't have an opportunity to form an effective system of the reproduction process management of the FAS, as depreciation charges are actually a tax exemption, which allows economic entities to transform them into additional income and use at their discretion.

The primary source of information for management decisions (accounting data on the status and movement of the main funds) does not reflect the real picture of the state of the FAS.

\section{CONCLUSION}

Thus, the depreciation fund of RSI enterprises is the primary source of renewal of FAS, which has lost its reproductive function now.

To restore that, it is necessary:

1. to legislatively fix the targeted use of the depreciation Fund and tighten the control of the state for its formation;

2. to set the real return on depreciation deductions above the rate of inflation;

3. that RSI enterprises should develop a clear and adequate depreciation strategy that corresponds to the current reproductive situation of FAS.

\section{References}

[1] M.A. Stolyarova, O.L. Shulgaty, M.R. Dzagoeva, L.I. Bestaeva and V.A. Kaitmazov, "Generalization of foreign experience in the reproduction and recording of fixed assets", International Journal of Applied Business and Economic Research, 2016, pp. 241-250

[2] A.A. Boyko and E.S. Rybakova, "Formation of investment resources of reproduction of the basic production assets of the enterprises of a machine-building complex", Bulletin of the Reshetnev Siberian State Aerospace University, vol. 16, 2007, pp.118-121

[3] A.A. Boyko and E.S. Rybakova, "Formation of investment resources of reproduction of the basic production assets of machine-building enterprises", Reshetnev Siberian State Aerospace University : Krasnoyarsk, 2009.

[4] I.V. Oliynyk, "Fixed assets management in the frameworks of classical and contemporary theories", Actual Problems of Economics, vol. 168, 2015, pp. 47-53.

[5] A.A. Stupina, A.A. Shigina, A.O. Shigin, M.V. Karaseva and S.N. Ezhemanskaja, "Automated intellectual system with the short-duration nature of feedback", Life Science, vol. 11, 2014, pp. 302-306.

[6] L. Ye, "Research on enterprise fixed assets management based on KMEANS clustering algorithm”, Agro Food Industry Hi-Tech, vol. 28, 2017, pp. 2540-2544.

[7] S.I. Tatynov, "Increasing the role of depreciation in the renewal of fixed capital of enterprises", Finances, vol. 6, 2011, pp. 163-169.

[8] J.L. Gissel, "A case of fixed asset accounting: Initial and subsequent measurement", Journal of Accounting Education, vol. 37, 2016, pp. 6166.

[9] Y. Vertakova, S. Klevtsov and M. Klevtsova, "Technology of fixed assets assessment in investigating the stability of the industrial complex of the region", Proceedings of the 26th International Business Information Management Association Conference - Innovation Management and Sustainable Economic Competitive Advantage: From Regional Development to Global Growth, 2015, pp. 3230-3236.

[10] G.S. Klychova, A.R. Zakirova, K.Z. Mukhamedzyanov, E.R. Sadrieva and A.S. Klychova, "Development of audit system for operations with fixed assets as a tool for efficiency improvement of social activity of the enterprise", Journal of Engineering and Applied Sciences, vol. 12, 2017, pp. 4966-4973.

[11] M.D. Mattei and N. Mattei, "Analysis of fixed and biased asset allocation rebalancing strategies", Managerial Finance, vol. 42, 2016, pp. $42-50$. 